\title{
SISTEM INFORMASI PELAYANAN ADMINISTRASI KEPENDUDUKAN DESA (SIPAKDE) BERBASIS WEB DENGAN FRAMEWORK CODEIGNITER
}

\author{
${ }^{1}$ Jaka Abdul Haris, ${ }^{2}$ Darmansyah, ${ }^{3}$ Donny Apdian, ${ }^{4}$ Anggi Elanda \\ E-mail : ${ }^{1}$ jakaharis10@gmail.com, ${ }^{2}$ darmansyah@ rosma.ac.id, ${ }^{3}$ donny@ rosma.ac.id, \\ 4anggi@rosma.ac.id
}

\begin{abstract}
Abstrak
Desa Kamojing sebelumnya telah menggunakan sebuah sistem informasi dari pemerintah pusat yaitu Sistem Informasi Manajemen Desa selanjutnya disebut SIMADE, akan tetapi SIMADE tersebut sudah tidak dapat bekerja secara optimal karena mengharuskan mengambil data dari Sistem Informasi Administrasi Kependudukan versi 5 atau SIAK 5 yang dimiliki oleh Direktorat Jenderal Kependudukan dan Pencatatan Sipil atau disingkat DISDUKCAPIL, sedangkan saat ini SIAK 5 tidak bisa mengeluarkan database penduduk yang dibutuhkan sehingga SIMADE ini tidak dapat berjalan. Sementara ini untuk menunjang berbagai pekerjaan dalam pengelolaan data masyarakat, Desa Kamojing memanfaatkan sistem manual yaitu buku register untuk pencatatan dan semi manual dengan aplikasi Microsoft Word dan Microsoft Excel untuk pendataan kependudukan. Sistem tersebut masih memiliki kelemahan, buku register dalam pencatatannya selain bisa terjadi kesalahan penulisan yang berakibat tidak validnya data, buku bisa basah dan rusak yang berakibat nantinya akan kesulitan saat pencarian data atau proses rekap data, dalam pembuatan surat pun juga tidak efektif karena setiap pembuatan surat yang berulang. Peneliti termotivasi untuk melakukan penelitian dan membuat Sistem Informasi Pelayanan Administrasi Kependudukan Desa (SIPAKDe) Berbasis Web Dengan Framework Codeigniter. Sistem informasi ini merupakan pengembangan dari sistem yang sudah ada dan mampu membantu pekerjaan perangkat desa. Peneliti menggunakan metode analisis PIECES (Performance, Information, Economic, Control, Efficiency, Service), untuk melakukan penelitiannya.
\end{abstract}

Kata Kunci : SIPAKDe, Web, Framework Codeigniter

\begin{abstract}
Kamojing Village has previously used an information system from the central government namely the Village Management Information System, hereinafter referred to as SIMADE, but SIMADE has not been able to work optimally because it requires taking data from the Population Administration Information System version 5 or SIAK 5 owned by the Directorate General of Population and Civil Registration or abbreviated as DISDUKCAPIL, while at present SIAK 5 cannot issue the required population database so that SIMADE cannot run. While this is to support a variety of work in community data management, Kamojing Village utilizes a manual system that is a register book for recording and semi manuals with Microsoft Word and Microsoft Excel applications for population data collection. The system still has weaknesses, the register book in its recording in addition to writing errors can occur which results in invalid data, the book can be wet and damaged which will later cause difficulties when searching for data or data recap process, in the making of letters is also ineffective because each letter making which is repeated. Researchers are motivated to conduct research and create a Web-Based Village Population Administration Information System (SIPAKDe) with a Codeigniter Framework. This information system is a development of an existing system and is able to assist the work of village officials. Researchers use the PIECES analysis method (Performance, Information, Economic, Control, Efficiency, Service), to conduct research.
\end{abstract}

Keywords: SIPAKDe, Web, Codeigniter Framework

Jurnal Interkom: Jurnal Publikasi Ilmiah Bidang Teknologi Informasi dan Komunikasi

Volume 14 Nomor 04 Bulan Januari - Tahun 2020 


\section{Pendahuluan}

Kemajuan teknologi informasi dari waktu ke waktu sangat cepat membawa dunia memasuki zaman yang mau tidak mau harus memanfaatkan teknologi informasi tersebut untuk membantu pekerjaan manusia. Inovasi teknologi saat ini telah terbukti memberikan sumbangan yang cukup besar di berbagai bidang baik dari bidang bisnis, pendidikan, sampai pada pemerintahan.

Saat ini Pemerintahan dari tingkat pusat sampai tingkat daerah sudah merasakan manfaat dari teknologi melalui penerapan $e$ government. E-government dapat didefinisikan sebagai sistem tata kelola pemerintahan berbasis elektronik, terutama internet. Sistem online ini diharapkan dapat meningkatkan hubungan antara pemerintah, masyarakat dan dengan pihak-pihak lain. Di sisi lain, pemerintah sebagai penyelenggara pelayanan publik dapat membuat kinerja birokrasi di Indonesia menjadi lebih baik dari sebelumnya. Hal ini dinilai penting karena hampir setiap warga negara akan berurusan dengan instansi pemerintahan untuk berbagai keperluan administrasi, perizinan bisnis, dan sebagainya

Penerapan teknologi dalam pemerintahan, baru diterapkan ditingkat pemerintah daerah dan dikota-kota besar saja, dalam hal ini penulis memberikan contoh tentang sistem kependudukan, sistem kependudukan yang ada saat ini hanya berjalan ditingkat pusat, provinsi, kota, dan tingkat kecamatan, desa atau kelurahan belum merasa diperbantukan dengan adanya sistem kependudukan, padahal desa adalah bagian dari pemerintahan yang berhadapan langsung dengan masyarakat.

Desa Kamojing sebagai salah satu instansi pemerintahan ditingkat desa di bawah kecamatan Cikampek, memiliki struktur organisasi mulai dari kepala desa yang memiliki tiga bawahan yaitu sekretaris desa, kepala seksi dan kepala urusan serta memiliki dua dusun yaitu dusun kamojing barat dan dusun kamojing timur dengan jumlah total rukun keluarga sebanyak lima dan rukun tetangga sebanyak dua belas. Desa Kamojing memiliki peran strategis untuk mengatur masyarakat yang ada di pedesaan demi mewujudkan pembangunan pemerintah. Dalam pelaksanaannya, Desa Kamojing menjalankan tugas pokok pemerintahan desa di Indonesia yaitu menyajikan informasi kependudukan, informasi desa, pendataan Kartu Tanda Penduduk (KTP), Kartu Keluarga (KK), mutasi penduduk, kelahiran, dan kematian adapun pelayanan surat-menyurat ditingkat desa meliputi pembuatan surat keterangan tidak mampu, surat keterangan tempat tinggal, surat keterangan usaha, surat perubahan data dan surat desa lainnya, namun saat ini semua kegiatan yang dilakukan masih secara manual.

Desa Kamojing sebelumnya telah menggunakan sebuah sistem informasi yang dibantukan dari pemerintah pusat yaitu Sistem Informasi Manajemen Desa selanjutnya disebut SIMADE, akan tetapi SIMADE tersebut sudah tidak dapat bekerja secara optimal karena mengharuskan mengambil data dari SIAK Direktorat Jenderal Kependudukan dan Pencatatan Sipil atau DUKCAPIL sedangkan saat ini DUKCAPIL tidak bisa mengeluarkan data yang dibutuhkan sehingga SIMADE ini tidak dapat berjalan. Sementara ini untuk menunjang berbagai pekerjaan dalam pengelolaan data masyarakat, desa kamojing memanfaatkan sistem manual yaitu buku register untuk pencatatan dan semi manual dengan aplikasi Microsoft Word dan Microsoft Excel untuk pendataan kependudukan.

Uraian dari proses yang sedang berjalan saat ini yaitu, masyarakat datang ke kantor desa dengan membawa persyaratan untuk proses pendataan, dan menemui bagian kepala urusan pemerintahan (KAUR), kemudian KAUR mengambil persyaratan dan mencatat pada buku register, jika pelayanan yang dibutuhkan adalah pembuatan atau perubahan KTP, KK, pembuatan akta lahir, akta kematian, dan keterangan pindah datang maka KAUR akan mengambil form isian dan menulis secara manual, namun jika pelayanan yang dibutuhkan adalah pembuatan surat maka KAUR akan melakukan proses input di komputer dengan software Microsoft office word, dalam proses input KAUR akan menanyakan hal hal terkait surat yang dibuat, 
misalnya surat domisili, maka harus ada keterangan seperti tanggal datang, dan alasan pembuatan surat, dalam proses output, form yang sudah diisi maupun surat yang sudah dicetak melalui proses tanda tangan kepala desa atau jika tidak ada maka sekretaris desa yang mewakilinya, baru akhirnya form atau surat tersebut dinyatakan sah dari tingkat desa untuk dibawa oleh masyarakat untuk keperluannya masing-masing.

Sistem tersebut masih memiliki kelemahan, buku register dalam pencatatannya selain bisa terjadi kesalahan penulisan yang berakibat tidak validnya data, buku bisa basah dan rusak yang berakibat nantinya akan kesulitan saat pencarian data atau proses rekap data, dalam pembuatan surat pun juga tidak efektif karena setiap pembuatan surat yang berulang, misalnya pembuatan surat keterangan tempat tinggal, surat keterangan tidak mampu dan lain sebagainya KAUR melakukan pengetikan ulang pada program Microsoft word, karena data sebelumnya tidak disimpan. Hal tersebut mengakibatkan kurangnya efektifitas dalam pengelolaan data kependudukan.

Pengelolaan informasi selain digunakan sebagai pengontrolan atau acuan kepala desa dalam pengambilan suatu keputusan, juga digunakan sebagai laporan kepada instansi yang terkait yaitu kantor kecamatan. Mengingat hal tersebut maka dibutuhkan sebuah sistem informasi yang mampu mempermudah dalam pengelolaan data serta dapat memberikan efektifitas pengelolaan data di desa kamojing.

Berdasarkan uraian tersebut peneliti termotivasi untuk membuat Sistem Informasi Pelayanan Administrasi Kependudukan Desa (SIPAKDE) Berbasis Web Dengan Framework Codeigniter. Sistem informasi ini merupakan pengembangan dari sistem yang sudah ada dan mampu membantu pekerjaan perangkat desa, dan penyajian informasi dalam bentuk website untuk keperluan publikasi desa.

\section{Tinjauan Pustaka}

\section{Sistem}

Menurut Marshall B.Romney dan Paul John Steinbart (2014:3), "sistem adalah serangkaian dua atau lebih komponen yang saling terkait dan berinteraksi untuk mencapai tujuan".

Menurut Mulyadi (2016:1), "Sistem pada dasarnya adalah sekelompok unsur yang erat berhubungan dengan yang lainnya, yang berfungsi bersama-sama untuk mencapai tujuan tertentu."

\section{Sistem Informasi}

Menurut Bambang Hartono (2013:16), "Sistem informasi adalah seperangkat komponen yang saling berhubungan, yang bekerja untuk mengumpulkan dan menyimpan data serta mengolahnya menjadi informasi yang digunakan".

Menurut Jeperson Hutahaean (2015:13), "Sistem informasi adalah suatu sistem didalam suatu organisasi yang mempertemukan kebutuhan pengelolaan transaksi harian, mendukung operasi, bersifat manajerial, dan kegiatan strategi dari suatu organisasi dan menyediakan pihak luar tertentu dengan laporan-laporan yang dibutuhkan".

\section{Administrasi Pemerintahan Desa}

Menurut Permendagri No. 47 Tahun 2016 Tentang Administrasi Pemerintahan Desa Ketentuan Umum pada Bab I Pasal 1, "Administrasi Pemerintahan Desa adalah keseluruhan proses kegiatan pencatatan data dan informasi mengenai Pemerintahan Desa pada Buku Register Desa".

\section{Website}

Menurut Murad, dkk (2013:49), "Web adalah sistem dengan informasi yang disajikan dalam bentuk teks, gambar, suara, dan lainnya yang tersimpan dalam sebuah server web internet yang disajikan dalam bentuk hypertext".

Menurut Arief (2012:7), "Web adalah salah satu aplikasi yang berisikan dokumendokumen multimedia (teks, gambar, suara, animasi, video) di dalamnya yang 
menggunakan protokol HTTP (hypertext transferprotocol) dan untuk mengaksesnya menggunakan perangkat lunak yang disebut browser".

\section{Code Igniter}

Menurut Hakim (2010:8), "CodeIgniter adalah sebuah framework PHP yang dapat membantu mempercepat developer dalam pengembangan aplikasi web berbasis PHP dibanding jika menulis semua kode program dari awal",

\section{Desa}

Menurut Undang-Undang Nomor 4 tahun 2014 tentang Desa, Bab I Ketentuan Umum Pasal 1, disebutkan bahwa "Desa adalah desa dan desa adat atau yang disebut dengan nama lain, selanjutnya disebut Desa, adalah kesatuan masyarakat hukum yang memiliki batas wilayah yang berwenang untuk mengatur dan mengurus urusan pemerintahan, kepentingan masyarakat setempat berdasarkan prakarsa masyarakat, hak asal usul, dan/atau hak tradisional yang diakui dan dihormati dalam sistem pemerintahan Negara Kesatuan Republik Indonesia”.

\section{METODE PENELITIAN}

Metodologi perancangan sistem yang digunakan peneliti dalam pengembangan sistem yaitu menggunakan metode waterfall model. Metode ini kerapkali dipergunakan oleh para analis sistem pada umumnya. Inti dari metode waterfall adalah pengerjaan dari suatu sistem dilakukan dengan cara berurutan /secara linear.

Metode pengumpulan data yang dilakukan oleh peneliti adalah dengan cara pengamatan (observation) dan studi pustaka, diantaranya sebagai berikut :

1. Pengamatan (observation)

Merupakan metode pengumpulan data melalui pengamatan langsung atau peninjauan secara cermat. Adapun pengamatan dilakukan untuk mendapatkan data yang diperlukan untuk menunjang penulisan penelitian ini.
2. Studi Pustaka

Metode untuk mendapatkan informasi dengan mencatat dan mempelajari bukubuku atau literature review yang berhubungan dengan penelitian dari berbagai sumber yang tertulis maupun elektronik. Sebagian besar penulis melakukan pengumpulan data dan metode di ambil dari situs-situs internet, dan sisanya dari buku cetak

3. Wawancara

Teknik pengumpulan data dengan cara komunikasi tanya jawab untuk mendapatkan informasi secara langsung kepada suatu pihak. Proses pengumpulan data, keterangan dan bahan-bahan yang diperlukan sebagai pembahasan dalam penelitian.

\section{Hasil Penelitian dan Pembahasan}

Berdasarkan pada hasil observasi dan penelitian yang telah dilakukan oleh peneliti maka hasil penelitian yang dapat dilaporkan adalah dengan dibuatkannya Sistem Informasi Pelayanan Administrasi Kependudukan Desa (SIPAKDe) di Desa Kamojing Kecamatan Cikampek Kabupaten Karawang.

Adapun implementasi hasil riset tersebut adalah sebagai berikut :

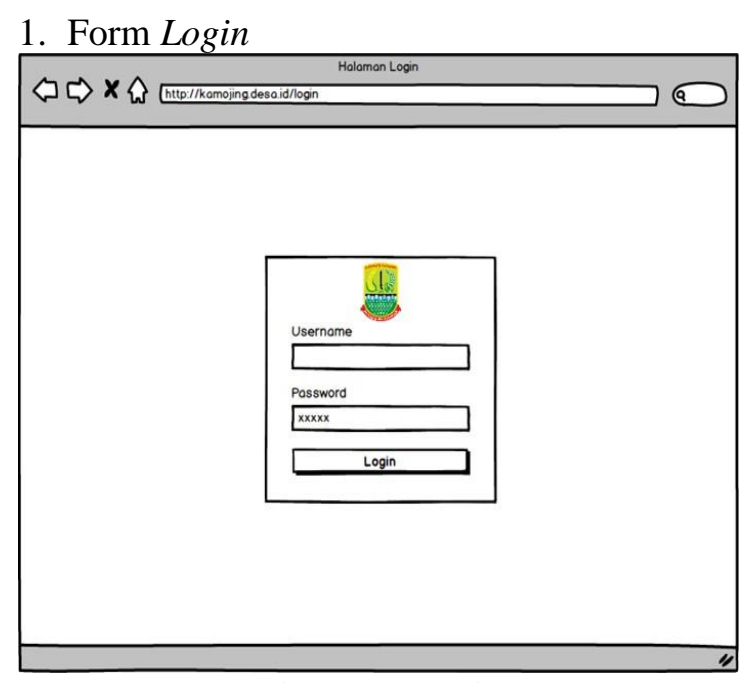

Gambar 1. Form login 
Mockup gambar 1 merupakan form login dari aplikasi SIPAKDe, dalam prosesnya, user melakukan input username dan password yang telah didaftarkan terlebih dahulu oleh superadmin, kemudian klik tombol login.

2. Tampilan user superadmin

a. Master desa

1) Data dasar desa

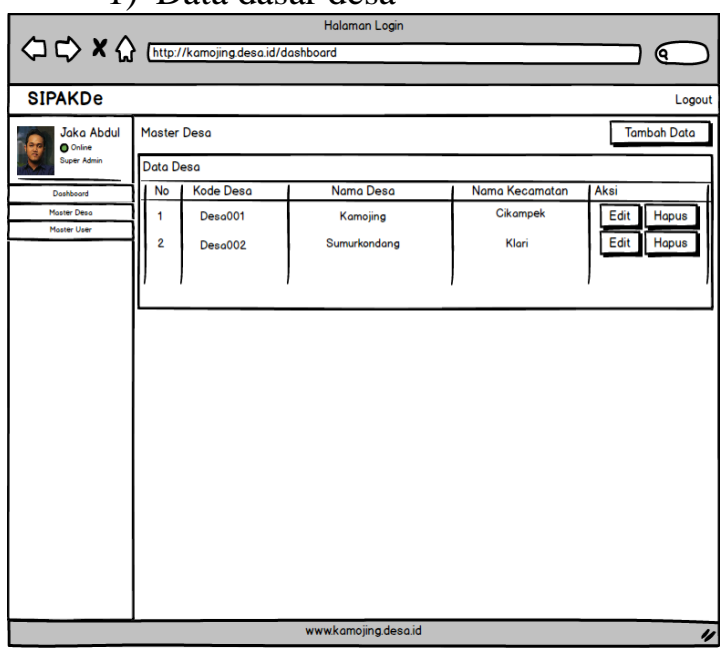

Gambar 2. Data Master Desa

Mockup gambar 2 merupakan tampilan data desa yang ada di aplikasi SIPAKDe, data detailnya berupa, nama desa, nama kecamatan, nama kepala desa, nama sekretaris desa, alamat, dan lain sebagainya, terdapat 3 (tiga) aksi yang bisa dilakukan user, yaitu tambah data desa, edit data desa, dan hapus data desa.

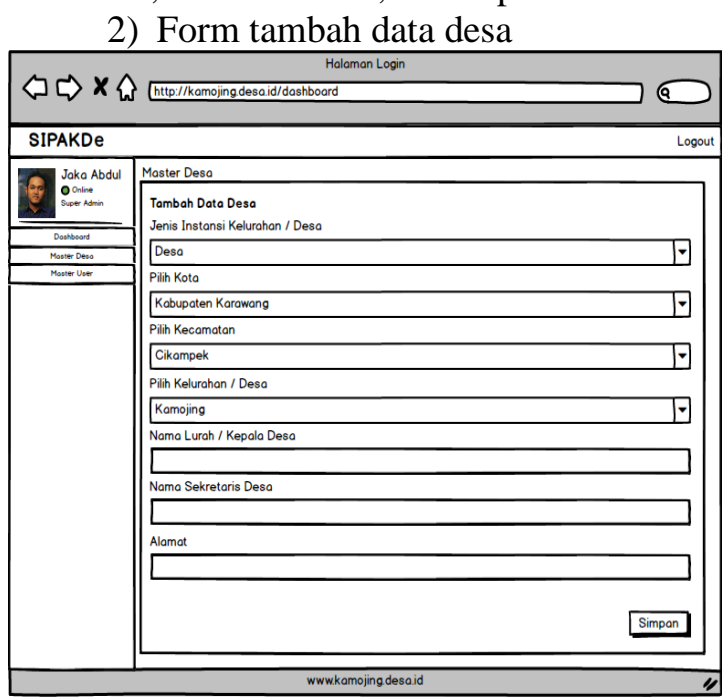

Gambar 3 Form Tambah Data Desa
Mockup gambar 3 merupakan tampilan form tambah data desa, data disini merupakan data profil desa, digunakan untuk keperluan, kop surat dan nama penandatangan pada surat, sehingga menjadi dinamis jika terjadi perubahan data (misal pergantian kepala desa).

\section{b. Master User}

1) Data Master User

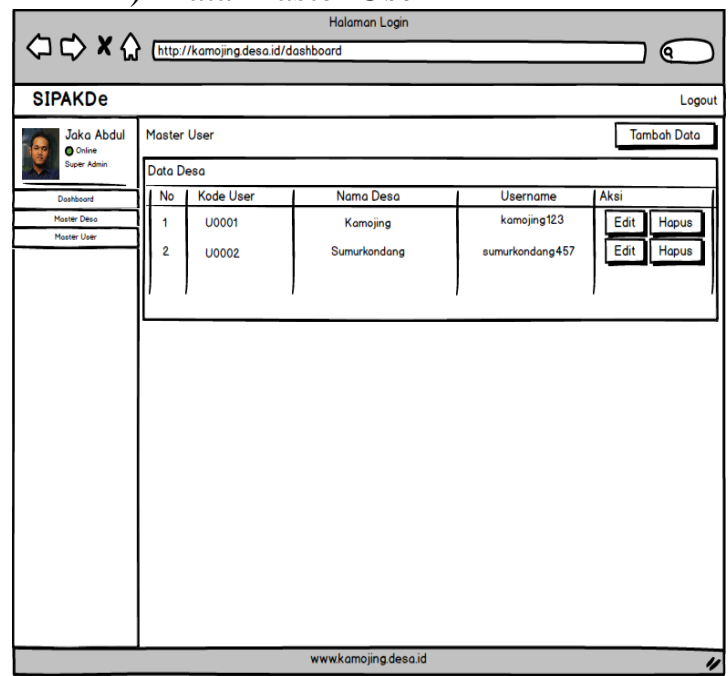

Gambar 4. Data Master User

Mockup gambar 4 merupakan tampilan data user yang ada di aplikasi SIPAKDe, data detailnya berupa, username, email, password dan nama desa, terdapat 3 (tiga) aksi yang bisa dilakukan user, yaitu tambah data user, edit data user, dan hapus data user.

\section{c. Tampilan user admin 1) Dashboard}

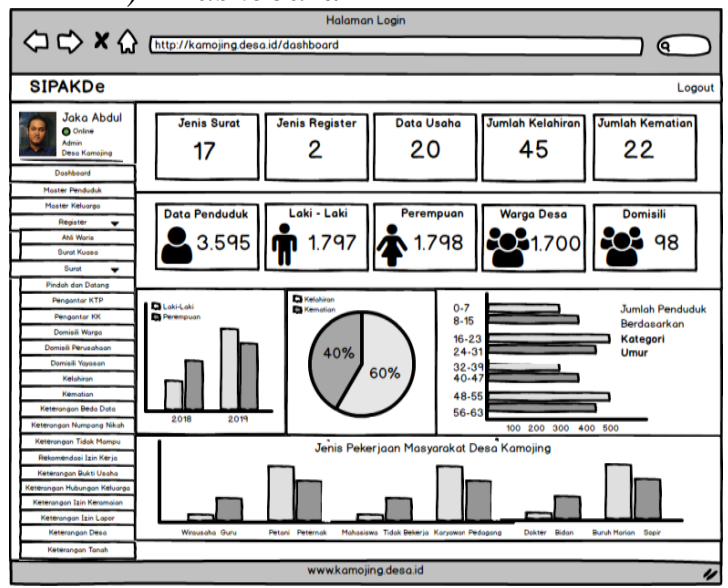

Gambar 5 Dashboard 
Mockup gambar 5 merupakan tampilan dashboard yang ada di aplikasi SIPAKDe, ada beberapa angka dan grafik yang ditampilkan, diantaranya data penduduk, grafik perbandingan kelahiran dan kematian, jenis pekerjaan yang ada ditiap desa, jumlah penduduk dalam kategori umur.

\section{2) Master penduduk}

a. Data master penduduk

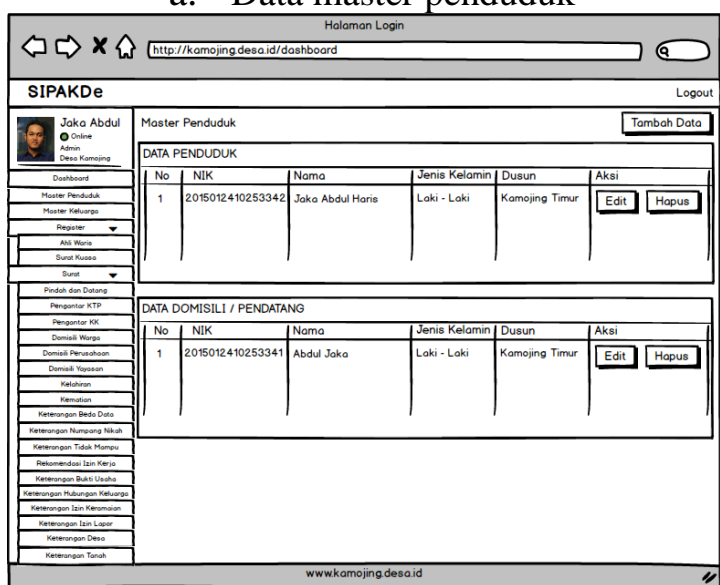

Gambar 6 Data Master Penduduk

Mockup gambar 6 merupakan tampilan data master penduduk yang ada di aplikasi SIPAKDe, data detailnya seperti data pada Kartu Tanda Penduduk, terdapat 3 (tiga) aksi yang bisa dilakukan user, yaitu tambah data penduduk, edit data penduduk, dan hapus data penduduk.

b. Tambah master penduduk

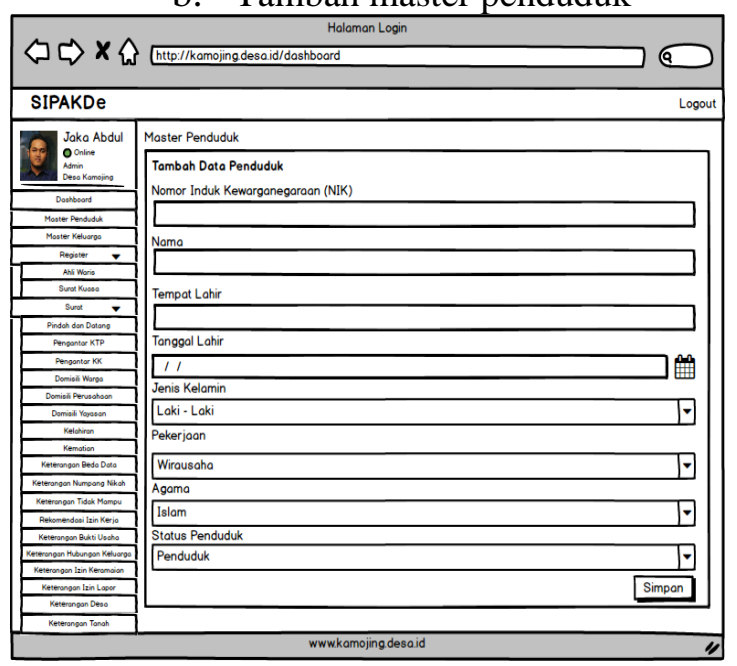

Gambar 7 Tambah Master Penduduk
Mockup gambar 7 merupakan tampilan form tambah data penduduk, data disini penduduk ini digunakan oleh menu lainnya, seperti menu data keluarga, atau dalam pembuatan surat.

c. Master keluarga

1) Data master keluarga

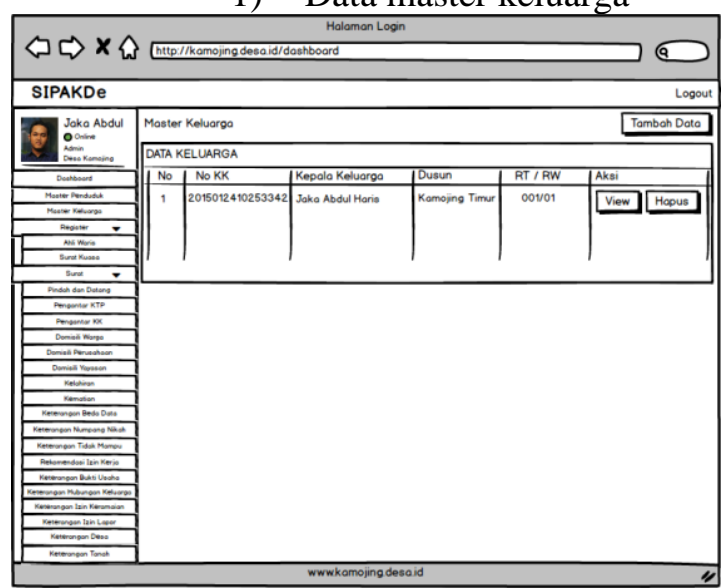

Gambar 8 Data master keluarga

Mockup gambar 8 merupakan tampilan data keluarga yang ada di aplikasi SIPAKDe, data detailnya nama kepala keluarga, nama dusun, dan data anggota keluarga, terdapat 3 (tiga) aksi yang bisa dilakukan user, yaitu tambah data keluarga, lihat data keluarga, dan hapus data keluarga.

2) Register ahli waris

Data register ahli waris

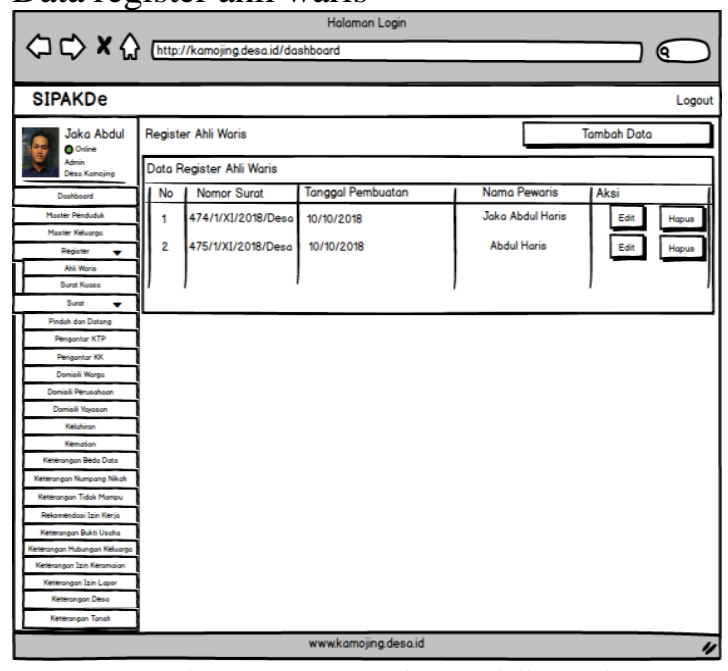

Gambar 9 Data register ahli waris

Mockup gambar 9 merupakan tampilan data register ahli waris, data yang ditampilkan berupa, nomor surat, tanggal pembuatan, nama 
pewaris, terdapat 3 (tiga) aksi yang bisa dilakukan user, yaitu tambah data register ahli waris, edit data register ahli waris, dan hapus data register ahli waris.

3) Register surat kuasa

Data register surat kuasa

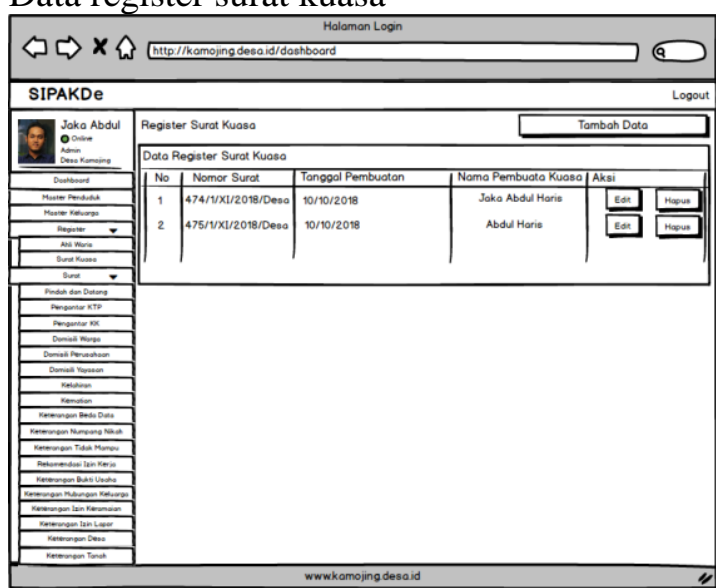

Gambar 10 Data register surat kuasa

Mockup gambar 10 merupakan tampilan data register surat kuasa, data yang ditampilkan berupa, nomor surat, tanggal pembuatan, nama pemberi kuasa, terdapat 3 (tiga) aksi yang bisa dilakukan user, yaitu tambah data register surat kuasa, edit data register surat kuasa, dan hapus data register surat kuasa.

4) Surat pindah dan surat datang

Data surat pindah dan surat datang

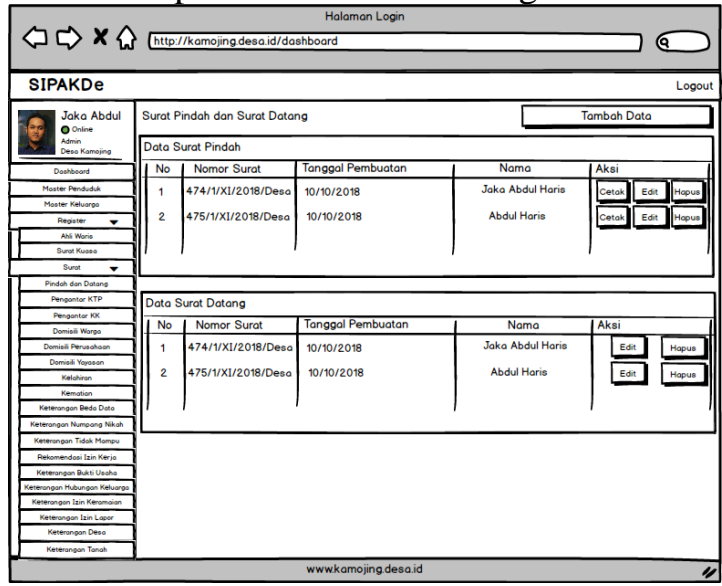

Gambar 11 Data surat pindah dan surat datang

Mockup gambar 11 merupakan tampilan data desa yang ada di aplikasi SIPAKDe, data yang ditampilkan berupa, nomor surat, tanggal pembuatan, dan nama masyarakat yang membuat surat, terdapat 3 (tiga) aksi yang bisa dilakukan user, yaitu tambah data surat pindah atau surat datang, edit data surat, dan hapus data surat.

d. Surat pengantar KTP

1) Data surat pengantar KTP

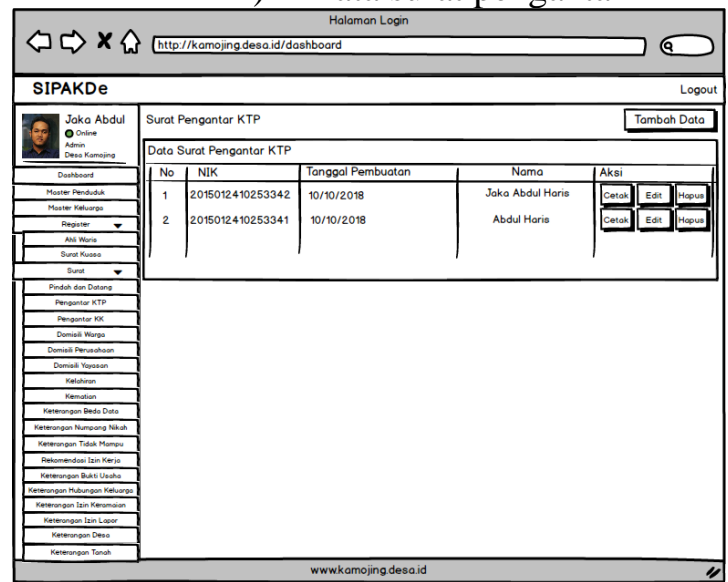

Gambar 12 Data surat pengantar Kartu Tanda Penduduk (KTP)

Mockup gambar 12 merupakan tampilan data surat pengantar Kartu Tanda Penduduk (KTP), data yang ditampilkan adalah Nomor Induk Kependudukan (NIK), Tanggal pembuatan surat dan Nama, terdapat 3 (tiga) aksi yang bisa dilakukan user, yaitu tambah data surat pengantar KTP, edit data surat pengantar KTP, dan hapus data surat pengantar KTP.

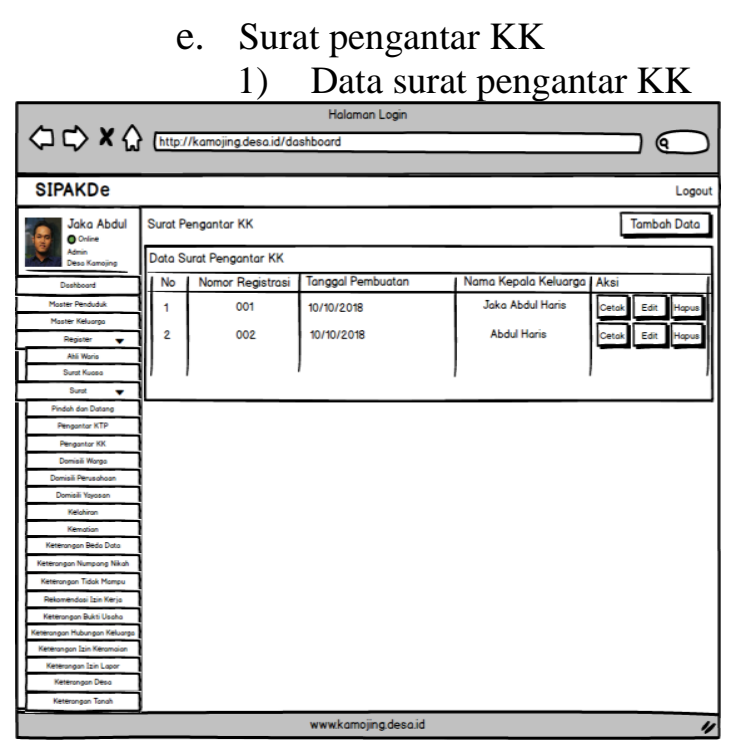

Gambar 13 Data surat pengantar Kartu Keluarga (KK) 
Mockup gambar 13 merupakan tampilan data surat pengantar Kartu Keluarga (KK), data yang ditampilkan adalah nomor registrasi (NIK), Tanggal pembuatan surat dan Nama, terdapat 3 (tiga) aksi yang bisa dilakukan user, yaitu tambah data surat pengantar KK, edit data surat, dan hapus data surat.

\section{f. Surat domisili warga}

1) Data surat domisili warga

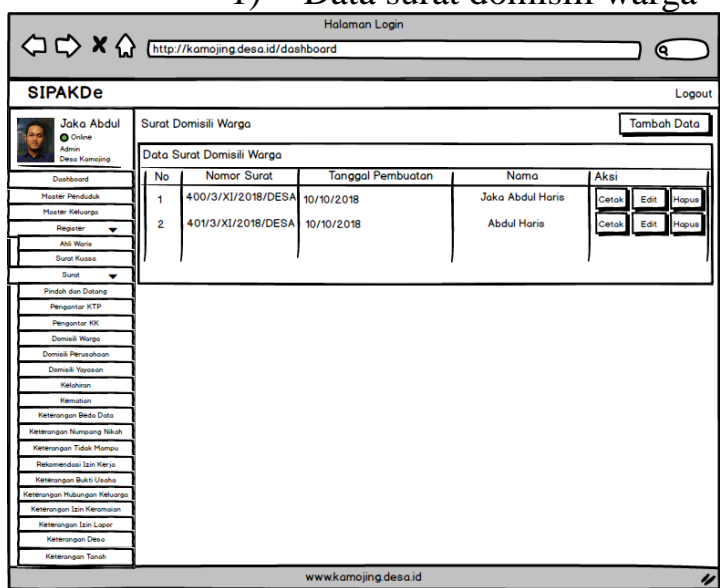

Gambar 14 Data surat domisili warga

Mockup gambar 14 merupakan tampilan data surat domisili warga, data yang ditampilkan adalah nomor surat, tanggal pembuatan surat dan nama, terdapat 3 (tiga) aksi yang bisa dilakukan user, yaitu tambah data surat domisili warga, edit data, dan hapus data.

g. Surat domisili perusahaan

1) Data surat domisili perusahaan

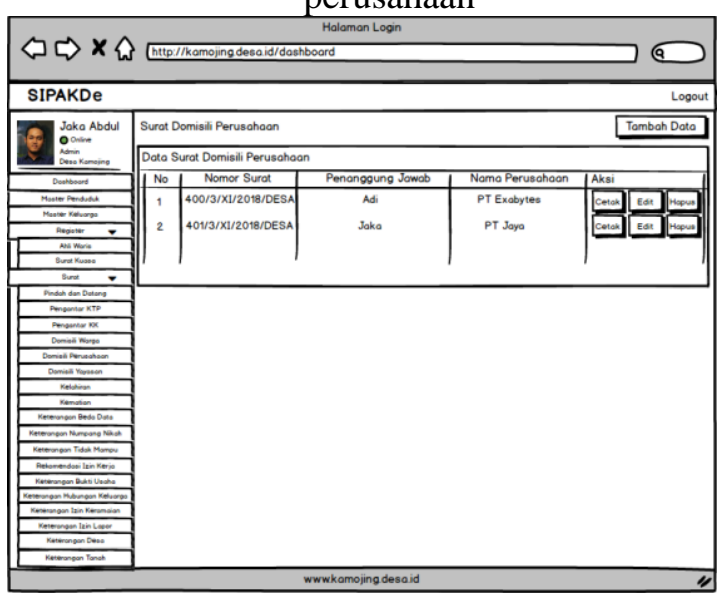

Gambar 15 Data surat domisili perusahaan

Mockup gambar 15 merupakan tampilan data surat domisili perusahaan, data yang ditampilkan adalah nomor surat, nama penanggung jawab dan nama perusahaan, terdapat 3 (tiga) aksi yang bisa dilakukan user, yaitu tambah data surat domisili perusahaan, edit data, dan hapus data.

2) Tambah surat domisili perusahaan

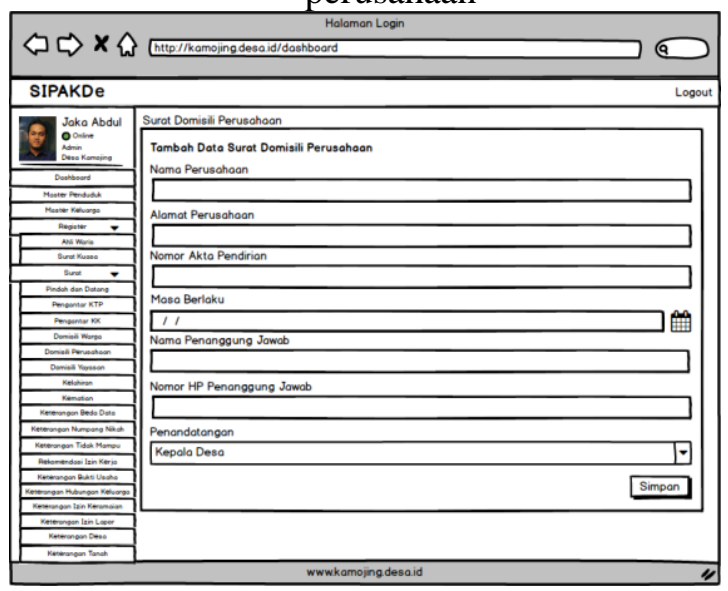

Gambar 16 Form tambah data surat domisili perusahaan

Mockup gambar 16 merupakan tampilan form tambah data surat domisili perusahaan, proses selanjutnya adalah mengisi detail surat seperti nama perusahaan, alamat perusahaan, nomor akta pendirian, masa berlaku, nama penanggung jawab, dan nomor hp penanggung jawab.

h. Surat domisili yayasan

1) Data surat domisili yayasan

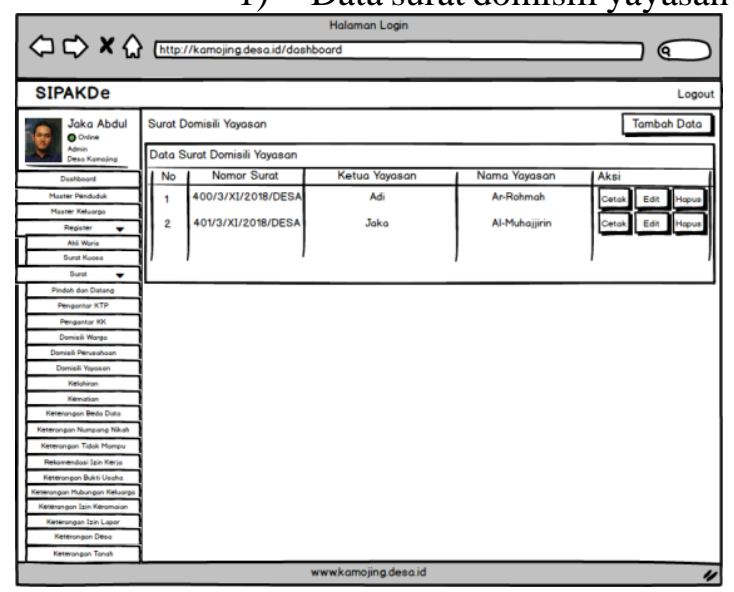

Gambar 17 Data surat domisili yayasan

Mockup gambar 17 merupakan tampilan data surat domisili perusahaan, data yang ditampilkan adalah nomor surat, nama ketua 
yayasan dan nama yayasan, terdapat 3 (tiga) aksi yang bisa dilakukan user, yaitu tambah data surat domisili yayasan, edit data, dan hapus data.

2) Edit surat domisili yayasan

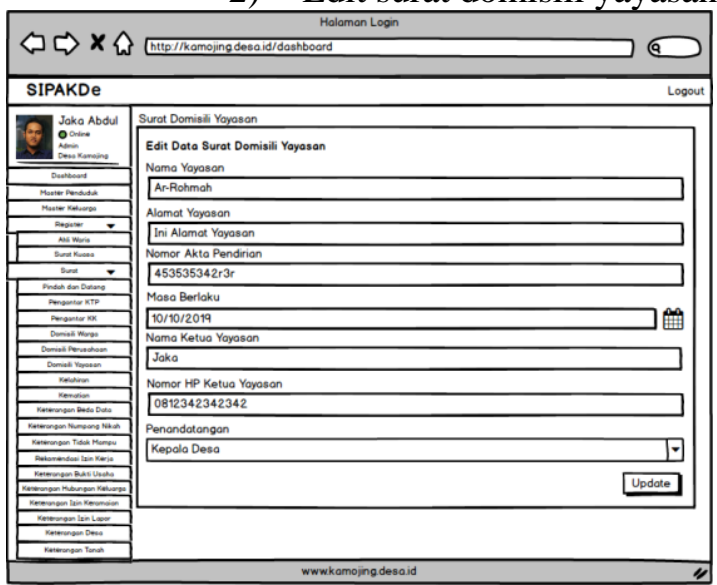

Gambar 18 Form edit data surat domisili yayasan

Mockup gambar 18 merupakan tampilan form edit data surat domisili yayasan, berfungsi untuk mengubah data surat yang sebelumnya sudah ada.

i. Surat kelahiran

1) Data surat kelahiran

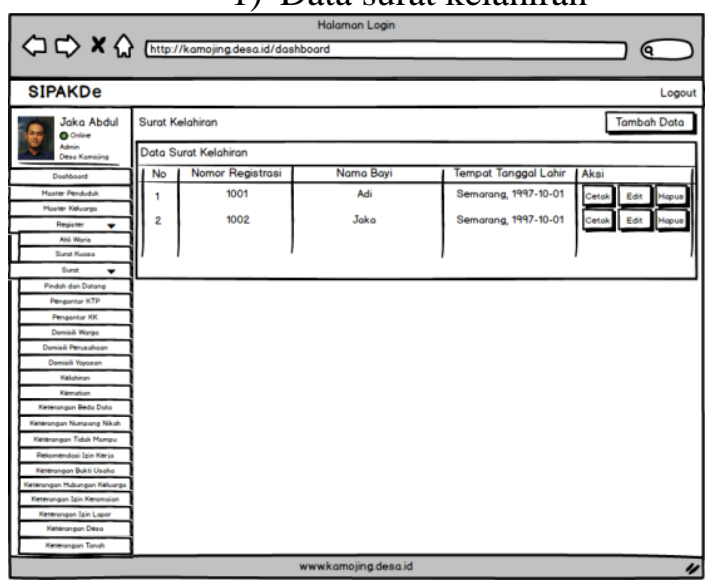

Gambar 19 Data surat kelahiran

Mockup gambar 20 merupakan tampilan data surat kelahiran, data yang ditampilkan adalah nomor registrasi, nama bayi, dan tempat tanggal lahir, terdapat 3 (tiga) aksi yang bisa dilakukan user, yaitu tambah data, edit data, dan hapus data surat kelahiran.
3) Tambah surat kelahiran

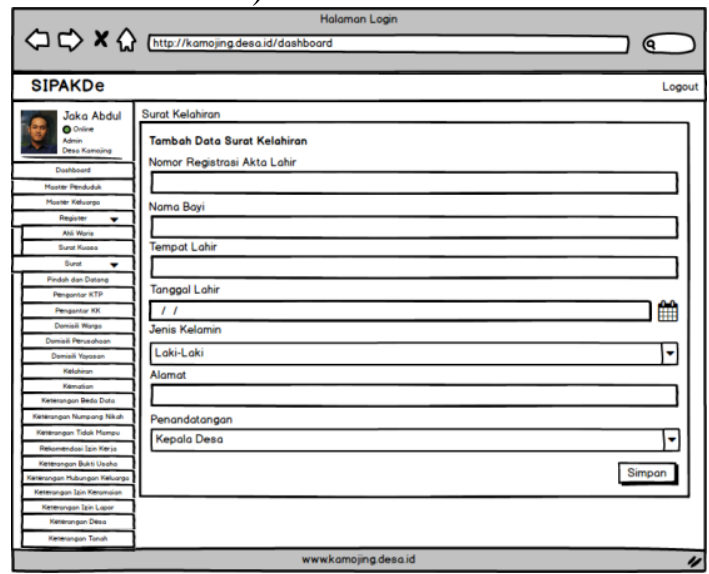

Gambar 21 Form tambah data surat kelahiran

Mockup gambar 22 merupakan tampilan form tambah data surat kelahiran, proses selanjutnya adalah mengisi detail surat seperti nomor registrasi akta lahir, nama bayi, tempat lahir, tanggal lahir, jenis kelamin, dan alamat.

j. Surat kematian

1) Data surat kematian

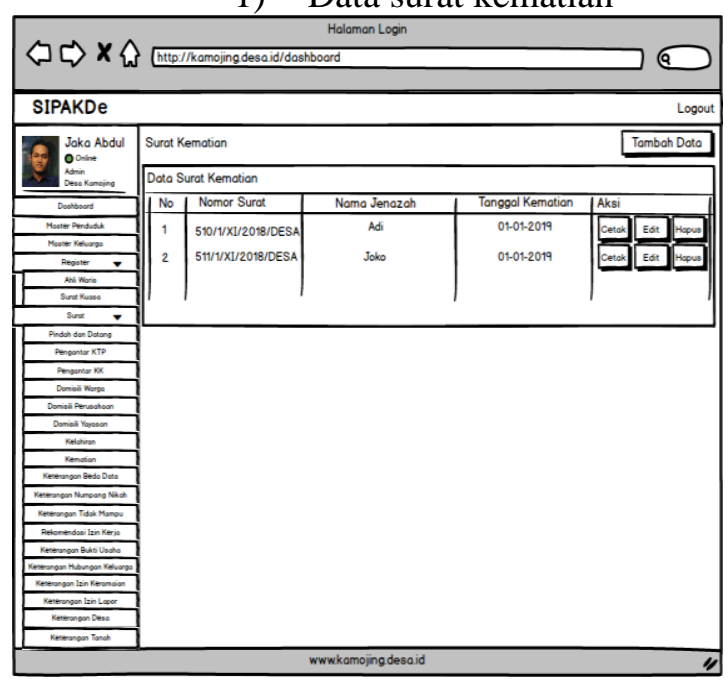

Gambar 23 Data surat kematian

Mockup gambar 23 merupakan tampilan data surat kematian, data yang ditampilkan adalah nomor surat, nama jenazah, tanggal kematian, terdapat 3 (tiga) aksi yang bisa dilakukan user, yaitu tambah data, edit data, dan hapus data surat kematian. 
a. Surat keterangan numpang nikah

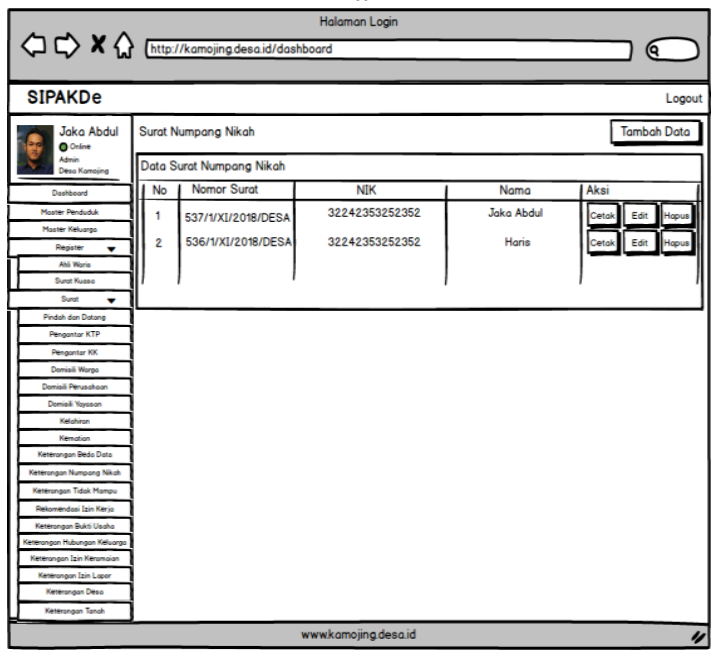

Gambar 24 Data surat numpang nikah

Mockup gambar 24 merupakan tampilan data surat numpang nikah, data yang ditampilkan adalah nomor surat, nik, dan nama, terdapat 3 (tiga) aksi yang bisa dilakukan user, yaitu tambah data, edit data, dan hapus data surat numpang nikah.

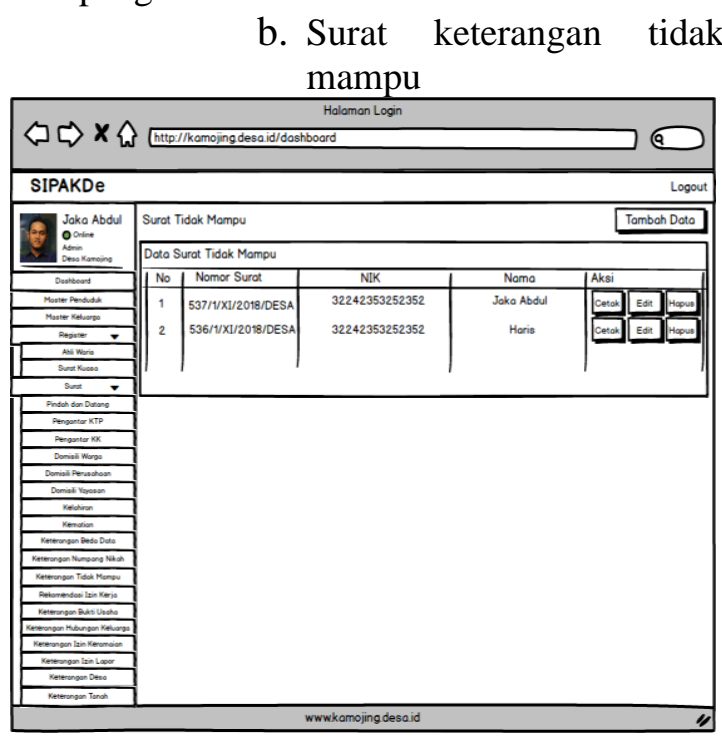

Gambar 25 Data surat keterangan tidak mampu

Mockup gambar 25 merupakan tampilan data surat tidak mampu, data yang ditampilkan adalah nomor surat, nik, dan nama, terdapat 3 (tiga) aksi yang bisa dilakukan user, yaitu tambah data, edit data, dan hapus data surat keterangan tidak mampu.

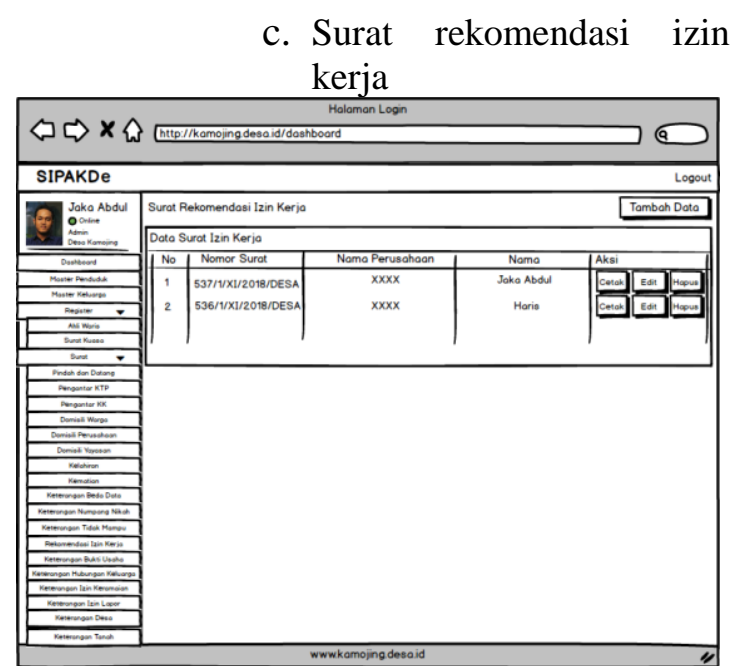

Gambar 26 Data surat rekomendasi izin kerja

Mockup gambar 26 merupakan tampilan data surat rekomendasi izin kerja, data yang ditampilkan adalah nomor surat, nik, dan nama, terdapat 3 (tiga) aksi yang bisa dilakukan user, yaitu tambah data, edit data, dan hapus data surat rekomendasi izin kerja.

d. Surat keterangan bukti usaha

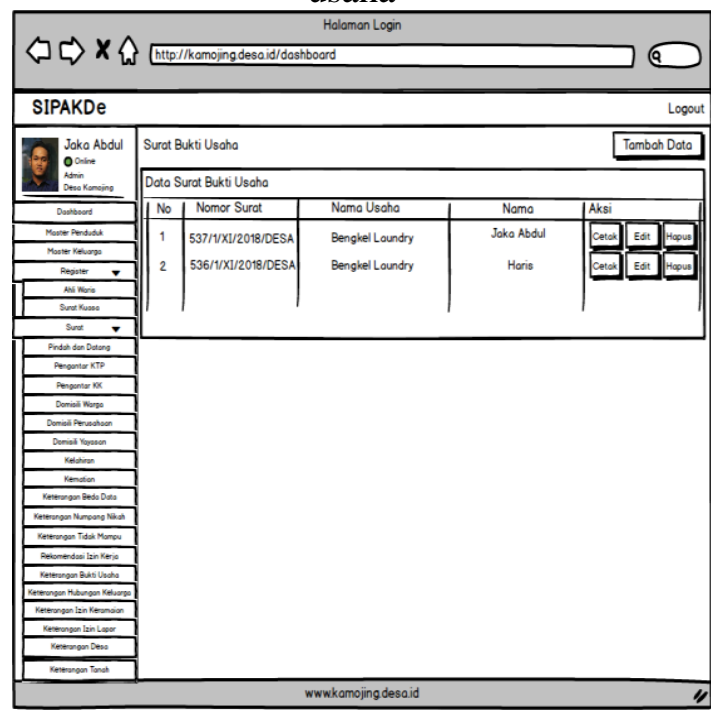

Gambar 27 Data surat keterangan bukti usaha

Mockup gambar 27 merupakan tampilan data surat bukti usaha, data yang ditampilkan adalah nomor surat, nama usaha, dan nama pemilik, terdapat 3 (tiga) aksi yang bisa dilakukan user, yaitu tambah data, edit data, dan hapus data surat keterangan bukti usaha. 
e. Surat keterangan hubungan keluarga

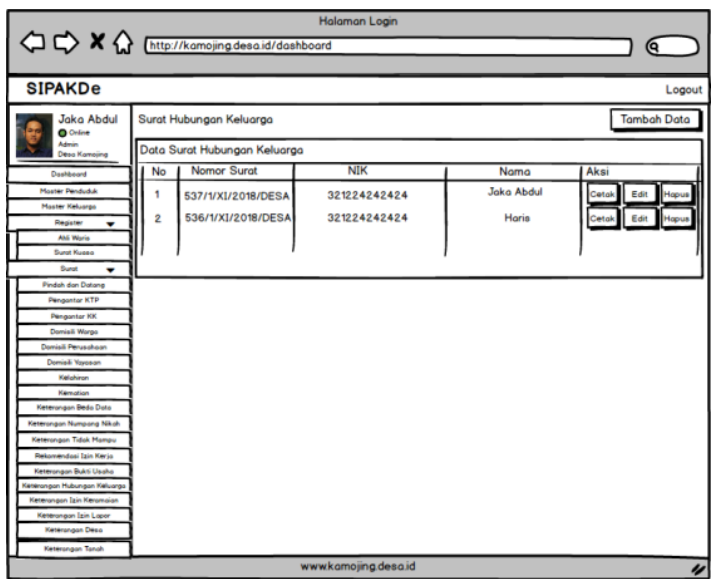

Gambar 28 Data surat keterangan hubungan keluarga

Mockup gambar 28 merupakan tampilan data surat keterangan hubungan keluarga, data yang ditampilkan adalah nomor surat, nik, dan nama, terdapat 3 (tiga) aksi yang bisa dilakukan user, yaitu tambah data, edit data, dan hapus data surat keterangan hubungan keluarga.

f. Surat keterangan izin keramaian

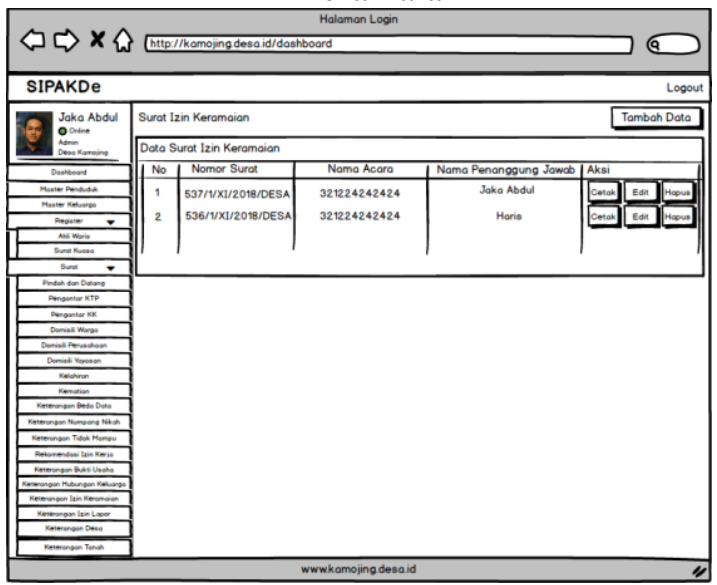

Gambar 29 Data surat izin keramaian

Mockup gambar 29 merupakan tampilan data surat izin keramaian, data yang ditampilkan adalah nomor surat, nama acara, dan nama penanggung jawab, terdapat 3 (tiga) aksi yang bisa dilakukan user, yaitu tambah data, edit data, dan hapus data surat izin keramaian. g. Surat keterangan izin lapor

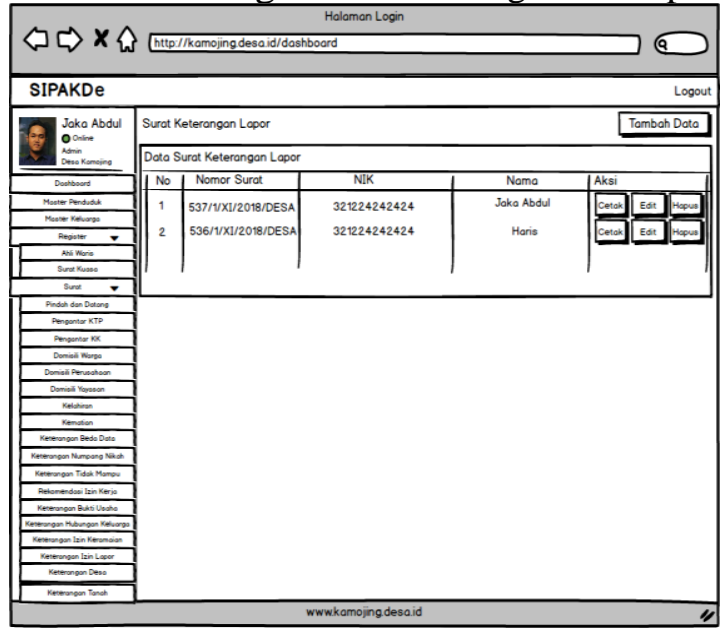

Gambar 30 Data surat keterangan izin lapor

Mockup gambar 30 merupakan tampilan data surat keterangan izin lapor, data yang ditampilkan adalah nomor surat, nik, dan nama, terdapat 3 (tiga) aksi yang bisa dilakukan user, yaitu tambah data, edit data, dan hapus data surat keterangan izin lapor.

h. Surat keterangan desa

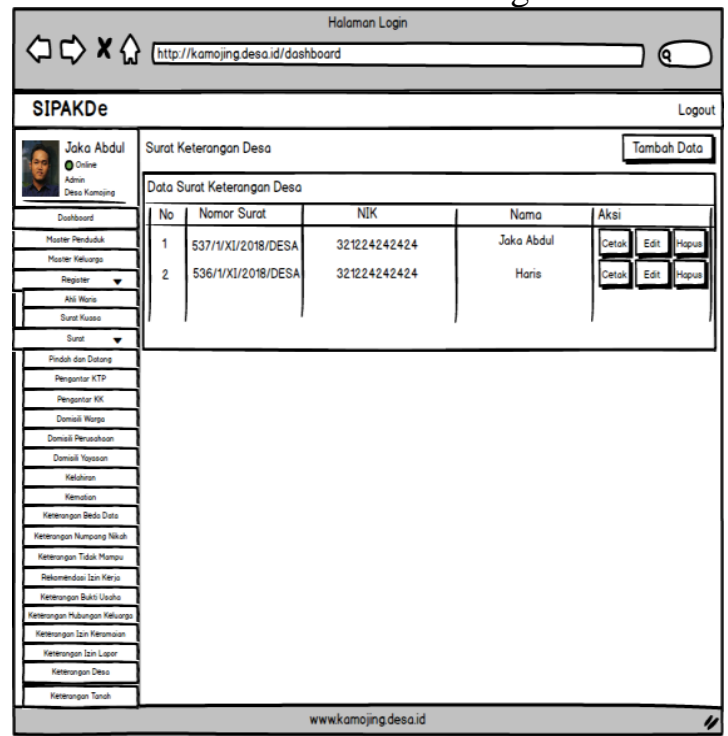

Gambar 31 Data surat keterangan desa

Mockup gambar 31 merupakan tampilan data surat keterangan desa, data yang ditampilkan adalah nomor surat, nik, dan nama, terdapat 3 (tiga) aksi yang bisa dilakukan user, yaitu tambah data, edit data, dan hapus data surat keterangan desa. 
i. Surat keterangan tanah

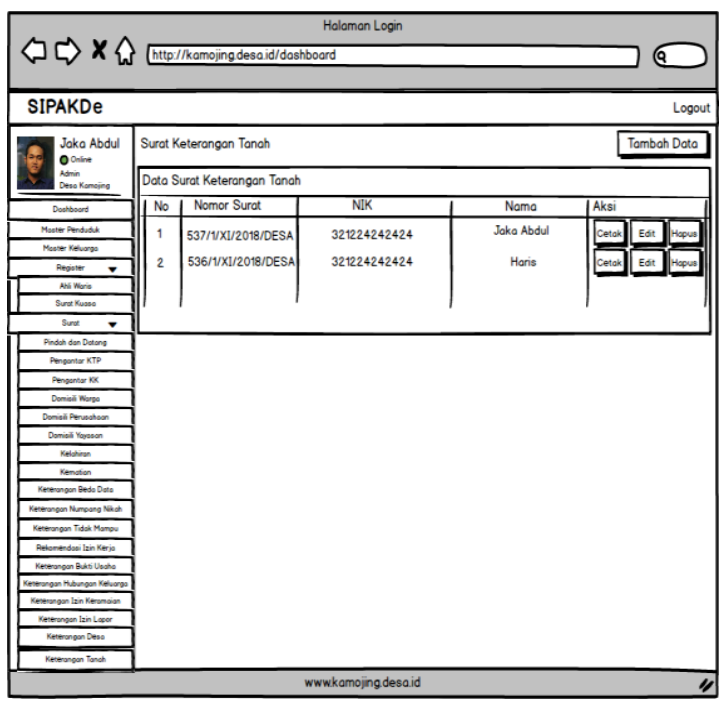

Gambar 32 Data surat keterangan tanah

Mockup gambar 32 merupakan tampilan data surat keterangan tanah, data yang ditampilkan adalah nomor surat, nik, dan nama, terdapat 3 (tiga) aksi yang bisa dilakukan user, yaitu tambah data, edit data, dan hapus data surat keterangan tanah.

x. Contoh hasil surat dalam pdf

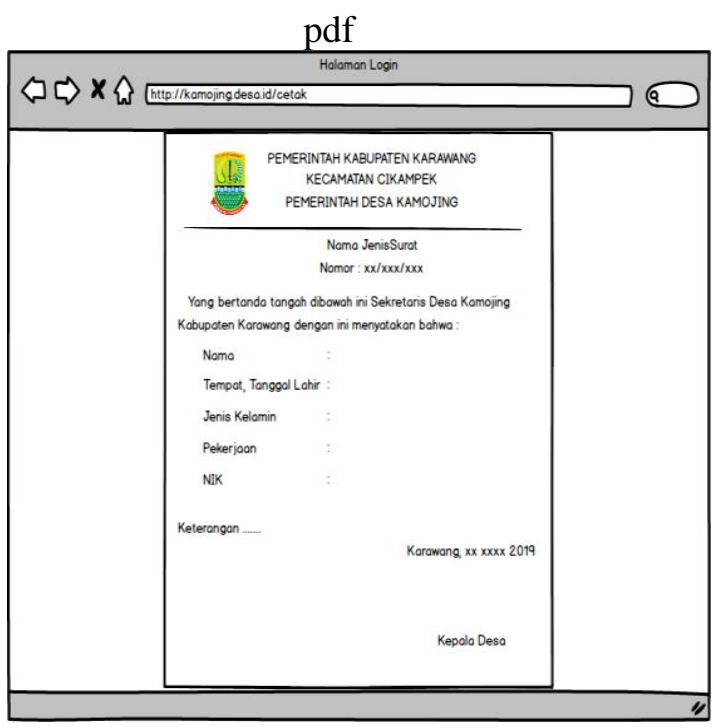

Gambar 33 Hasil cetak pdf

Mockup gambar 33 merupakan tampilan cetak surat dalam bentuk pdf, format surat disesuaikan dengan jenis surat yang dibuat

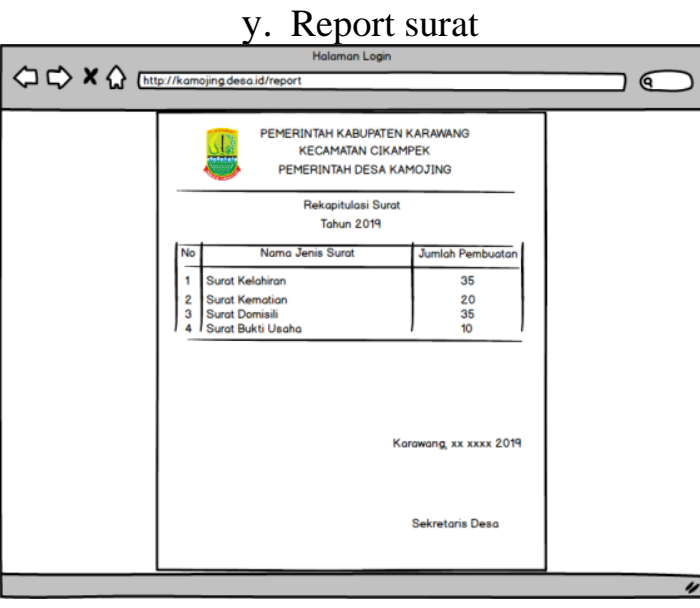

Gambar 34 Report surat

Mockup gambar 34 merupakan tampilan report /laporan surat dalam bentuk pdf, laporan yang ditampilkan diambil dari jumlah surat yang dikeluarkan desa setiap tahunnya.

\section{Kesimpulan Dan Saran}

\section{Kesimpulan}

Berdasarkan hasil penelitian yang telah dilakukan maka dapat diambil kesimpulan, sebagai berikut :

1. Setelah dibuatnya perancangan program Sistem Informasi Pelayanan Administrasi Kependudukan Desa (SIPAKDe), proses penyimpanan menjadi lebih terintegrasi, sehingga pengelolaan data kependudukan dan manajemen surat menjadi lebih cepat.

2. Setelah dibuatnya program Sistem Informasi Pelayanan Administrasi Kependudukan Desa (SIPAKDe), dalam prosesnya pihak desa dapat memonitoring data secara real time.

3. Setelah dilakukan proses kuesioner terhadap sumber daya manusia (SDM) di Desa Kamojing yang datanya sudah dianalisis menggunakan SPSS (Statistical Package for the Social Sciences), dinyatakan bahwa SDM tersebut mampu untuk mengoperasikan sistem ini.

\section{Saran}

Peneliti berdasarkan pada hasil penelitian pun memberikan beberapa saran, 
dengan mengacu pada modul-modul dari program Sistem Informasi Pelayanan Administrasi Kependudukan Desa (SIPAKDe) yang sudah dirancang, agar lebih optimal, diantaranya :

1. Dalam sistem administrasi masih perlunya dikembangkan menjadi sistem yang lebih kompleks, misalnya tambah akses ketua RT, ketua RW dan Kepala Dusun, sehingga proses administrasi kependudukan benar-benar sudah terintegrasi sampai kepada level paling bawah pemerintahan desa.

2. Dalam sistem kependudukan, sistem yang dibuat ini kedepannya bisa dikembangkan lagi menjadi pemetaan penduduk desa dalam bentuk peta desa, sehingga memudahkan dalam pencarian informasi penduduk, karena disajikan dalam bentuk seperti peta.

\section{Daftar Pustaka}

Romney, Marshal B dan Paul John Steinbart. 2014. Sistem Informasi Akuntansi. Jakarta: Selemba Empat

Mulyadi. 2016. Sistem Akuntansi Edisi 4. Jakarta: Salemba Empat.

Hartono, Bambang. 2013. Sistem Informasi Manajemen Berbasis Komputer. Jakarta: Rineka Cipta.

Hutahaean, Jeperson. 2015. Konsep Sistem Informasi. Yogyakarta: Deepublish.

Undang-Undang Nomor 4 tahun 2014 tentang Desa.

Permendagri No. 47 Tahun 2016 Tentang Administrasi Pemerintahan Desa.

Arief, M.Rudyanto. 2011. Pemrograman Web Dinamis Menggunakan PHP \& MySql. Yogyakarta: Penerbit Andi.

Murad, Dina Fitria, dkk. 2013. Aplikasi Intelligence Website Untuk Penunjang Laporan PAUD pada HIMPAUDI Kota Tangerang. ISSN: 1978-8282. Jurnal CCIT Vol.7 No.1-September 2013. Tangerang: Perguruan Tinggi Raharja. 